\title{
A synthesis is emerging between biodiversity-ecosystem function and ecological resilience research: reply to Mori
}

Article

Accepted Version

Oliver, T. H., Heard, M. S., Isaac, N. J.B., Roy, D. B., Procter, D., Eigenbrod, F., Freckleton, R., Hector, A., Orme, C. D. L., Petchey, O. L., Proença, V., Raffaelli, D., Blake Suttle, K., Mace, G. M., Martín-López, B., Woodcock, B. A. and Bullock, J. M. (2016) A synthesis is emerging between biodiversityecosystem function and ecological resilience research: reply to Mori. Trends in Ecology \& Evolution, 31 (2). pp. 89-92. ISSN 0169-5347 doi: https://doi.org/10.1016/j.tree.2015.12.008 Available at https://centaur.reading.ac.uk/57273/

It is advisable to refer to the publisher's version if you intend to cite from the work. See Guidance on citing.

To link to this article DOI: http://dx.doi.org/10.1016/j.tree.2015.12.008

Publisher: Elsevier

All outputs in CentAUR are protected by Intellectual Property Rights law, including copyright law. Copyright and IPR is retained by the creators or other copyright holders. Terms and conditions for use of this material are defined in 
the End User Agreement.

www.reading.ac.uk/centaur

\section{CentAUR}

Central Archive at the University of Reading

Reading's research outputs online 


\section{A synthesis is emerging between biodiversity-ecosystem function and ecological resilience research - Reply to Mori}

Tom H. Oliver, ${ }^{1,2 *}$ Matthew S. Heard, ${ }^{2}$ Nick J.B.Isaac, ${ }^{2}$ David B. Roy, ${ }^{2}$ Deborah Procter, ${ }^{3}$ Felix Eigenbrod, ${ }^{4}$ Rob Freckleton, ${ }^{5}$ Andy Hector, ${ }^{6} \mathrm{C}$. David L. Orme, ${ }^{7}$ Owen L. Petchey, ${ }^{8}$ Vânia Proença, ${ }^{9}$ David Raffaelli, ${ }^{10} \mathrm{~K}$. BlakeSuttle, ${ }^{11}$ Georgina M.Mace, ${ }^{12}$ Berta Martín-López, ${ }^{13,14}$ Ben A.Woodcock, ${ }^{2}$ and James M.Bullock ${ }^{2}$

${ }^{1}$ School of Biological Sciences, University of Reading, Reading, Berkshire, RG6 6AS, UK

${ }^{2}$ NERC Centre for Ecology and Hydrology, Wallingford, UK

${ }^{3}$ Joint Nature Conservation Committee, UK

${ }^{4}$ University of Southampton, UK

${ }^{5}$ University of Sheffield, UK

${ }^{6}$ Department of Plant Sciences, University of Oxford, UK

${ }^{7}$ Imperial College London, UK

8Institute of Evolutionary Biology and Environmental Studies, University of Zurich, Switzerland

${ }^{9}$ Instituto Superior Técnico, University of Lisbon, Portugal

${ }^{10}$ University of York, UK

${ }^{11}$ Department of Earth and Planetary Science, University of California, Berkeley, CA, USA

${ }^{12}$ University College London, UK

${ }^{13}$ Faculty of Sustainability, Institute of Ethics and Transdisciplinary Sustainability Research, Leuphana University of Lüneburg, Germany

Corresponding author: T.H. Oliver (t.oliver@reading.ac.uk) 
A recent paper by Mori [1] states the need for a unification of studies of 'engineering' and 'ecological' frameworks of resilience. Engineering resilience focuses on the capacity of a system to recover to equilibrium following some kind of perturbation, whilst ecological resilience explicitly recognizes multiples stable states and the capacity for systems to resist 'regime shifts' between alternate states. We find Mori's argument somewhat surprising given the number of recent biodiversity-ecosystem functioning studies (B-EF) that incorporate aspects of both resistance and recovery [e.g. see references in 2, 3]. We would argue that a synthesis is well underway and that apparent discrepancies are more due to differences in the spatial, temporal and systems scale of focus, and ambiguities in defining this study context, rather than any fundamental incompatibilities in conceptual frameworks.

With regards to our recent review on the mechanisms which underpin the resilience of ecosystem functions [3], Mori states: "To avoid confusion, resilience in this case should be explicitly termed as recovery or defined as the analogy of engineering resilience". We clearly consider both recovery and resistance mechanisms that promote the resilience of ecosystem functions. It is unclear what would be the benefit of narrowing the focus to recovery or engineering resilience.

Mori appears to feel that although there is some consideration of resistance in recent BEF research (red text in his Box 1), it does not adequately embrace some of the concepts in the 'ecological resilience' definition, such as the potential for alternative stable states. We clearly define resilience at the level of an individual function, specifically as "the degree to which the ecosystem function can resist or recover rapidly from environmental perturbations, thereby maintaining function above a socially acceptable level” [3]. This definition does not preclude the existence of alternative stable states of the underlying 
system, and, indeed, we include the potential to shift to alternate states that provide lower function delivery as one of several mechanisms underpinning the provision of resilient ecosystem functions. However, there are many other factors that operate at finer scales of biological organisation, such as the species-level (e.g. genetic variability, sensitivity to environmental change, adaptive phenotypic plasticity, Allee effects) and the communitylevel (e.g. correlation between response and effect traits, functional redundancy, network interaction structure). Most importantly, we feel that a focus on system state (relative to an assumed equilibrium) is not particularly helpful. The ecological resilience literature is somewhat vague with regards to what aspects of the system should be resistant in the face of an environmental perturbation. The relevant response is varyingly defined as the system 'state', the 'persistence of relationships among state variables within the system', or the 'ways of functioning' [4]. In our review, we promote a definition focusing on functions that are delivered by a system, because biological systems are clearly dynamic, not least because the environment is continually changing. So even a system close to equilibrium would show changes in state, not to mention that many systems of interest (e.g. agro-ecosystems) are far from any equilibrium, or that an equilibrium may not even exist [5]. Therefore, we feel it does not make sense to focus on inconstancy of system state variables, nor their interrelationships; not least because changes in system state can actually ensure ecosystem functions are maintained (the example we give is that of species turnover in bee communities under climate change, which allow resilient pollination functions). Indeed, the ecological resilience (ER) literature itself highlights the importance of internal system reorganisations as a mechanism of maintaining resilience in the face of perturbations ['adaptive capacity'; 4]. This clearly involves changes in a system state variables and their inter-relationships. Similarly, in the B-EF literature, as Mori states, the stabilizing effects of 
biodiversity on ecosystem functioning are often realized through dynamic processes such as asynchrony and compensation amongst species [6]. So both camps, - the B-EF and ER research fields, seem to be in agreement here: it is not invariance in the system variables which is important, but the maintenance of the ecosystem functions that the system provides.

Although Mori calls for greater synthesis, we suggest that the two research fields of B-EF and ER have already started to converge. Traditionally, B-EF research has certainly adopted a more reductionist (and empirical) approach in contrast to holistic systems thinking of ER. As a consequence, original B-EF studies were conducted in small-scale experiments often focusing on a single function (e.g. plant productivity) and over limited time scales. However, recent research has considered a wider range of ecosystem functions and incorporated study of multiple functions simultaneously [e.g. 7]. Studies have moved from simply considering species richness of assemblages to functional diversity and interactions between species in wider food web networks [8]. Empirical studies have also been conducted over increasingly larger spatial scales [e.g. 9] and across scales [e.g. 7], moving BEF increasingly in the direction of a broader research framework. Similarly, in the ER research field, key developments have been made from the original abstract theories of systems and simple analogies with real-world examples, to recent progress towards testing and implementation of these theories [e.g. through quantification of early warning systems; 10].

To avoid further confusion, however, reducing ambiguity in the study system context is critical [11]. We propose that many of the apparent discrepancies between the B-EF and ER research fields are simply a result of researchers focusing at different temporal or spatial 
scales and talking at cross purposes. We highlight some of these apparent discrepancies and their potential reconciliation in Table 1.

To conclude, both B-EF and ER approaches had initial weaknesses, such as the limited focus of empirical B-EF studies and the limited approach to quantification in more abstract, holistic ER theories. However, researchers in both fields have recognised this and, by increasing the scope of B-EF studies and adopting a more empirical perspective on ER theories, the two fields are now beginning to merge. It is hoped that this emerging synthesis will help in understanding, predicting and delivering solutions for the management of resilient ecosystem functions [12]. 
Table 1 - Perceived discrepancies in biodiversity-ecosystem function (B-EF) versus ecological resilience (ER) literature and potential reconciliation. To aid researchers a more extensively referenced version of this table is available online (see Online Supplementary Material Table S1).

\begin{tabular}{|c|c|c|}
\hline Perceived discrepancy & Further details & Clarification/ potential reconciliation \\
\hline $\begin{array}{l}\text { B-EF literature has } \\
\text { traditionally focused } \\
\text { primarily on single ecosystem } \\
\text { functions in isolation (e.g. } \\
\text { plant productivity), whilst ER } \\
\text { literature comprises a more } \\
\text { holistic view of entire } \\
\text { ecosystems (and even socio- } \\
\text { ecological systems). }\end{array}$ & $\begin{array}{l}\text { In recent years B-EF research has rapidly } \\
\text { expanded beyond single ecosystem functions } \\
\text { such as plant productivity to consider a varied } \\
\text { range of functions in isolation as well as to } \\
\text { consider multi-functionality [e.g. 7]. Similarly, } \\
\text { attempts to test and apply the abstract } \\
\text { concepts of ER literature have led to } \\
\text { examination of specific systems and ecosystem } \\
\text { functions. }\end{array}$ & $\begin{array}{l}\text { The two fields of research appear to be converging. To } \\
\text { facilitate this bridging, it remains essential for studies to be } \\
\text { specific about the characteristics of a system they are } \\
\text { measuring, the disturbance regime and the spatial and } \\
\text { temporal scale of interest (see main text). }\end{array}$ \\
\hline $\begin{array}{l}\text { B-EF literature focusses on } \\
\text { stability and equilibrium and } \\
\text { ignores the existence of } \\
\text { alternate stable states. The } \\
\text { existence of alternate stable } \\
\text { states is a requisite for ER. }\end{array}$ & $\begin{array}{l}\text { ER definitions concern the likelihood of a } \\
\text { system crossing thresholds between alternate } \\
\text { stable states ('regime shifts'). A system need } \\
\text { not have high constancy to be resilient- it may } \\
\text { be dynamic around a semi-stable equilibrium } \\
\text { (i.e. staying within a 'domain of attraction'). } \\
\text { Therefore ER authors have suggested that } \\
\text { stability is not a relevant measure of resilience } \\
\text { and may even lead to contradictory } \\
\text { management outcomes (also see below). }\end{array}$ & $\begin{array}{l}\text { The key point here is whether the focus is on system state } \\
\text { variables or ecosystem functions provided by the system. If } \\
\text { the focus is the latter, then studies do not rely on quantifying } \\
\text { return to some equilibrium state; nor, indeed, do they need } \\
\text { to posit the existence of alternate stable states as do ER } \\
\text { studies (and some authors have questioned the extent to } \\
\text { which these really exist [5]). With a focus on ecosystem } \\
\text { functions, any system is suitable for study, even those that } \\
\text { are managed far from any stable equilibrium (i.e. most } \\
\text { managed ecosystems). }\end{array}$ \\
\hline $\begin{array}{l}\text { Managing for stability of } \\
\text { ecosystem functions (as } \\
\text { informed under a B-EF }\end{array}$ & $\begin{array}{l}\text { This issue is often highlighted in the ER } \\
\text { literature with a frequently cited example } \\
\text { being the management of woodlands to }\end{array}$ & $\begin{array}{l}\text { Rather than a fundamental disagreement, the discrepancy } \\
\text { here is simply a result of a focus on different spatial and } \\
\text { temporal scales. If both approaches adopt a large-scale }\end{array}$ \\
\hline
\end{tabular}




\begin{tabular}{|c|c|c|}
\hline $\begin{array}{l}\text { framework) can be } \\
\text { detrimental in the longer } \\
\text { term. }\end{array}$ & $\begin{array}{l}\text { prevent fires. If fires are regularly suppressed } \\
\text { (i.e. to provide stable ecosystem functions } \\
\text { from woodlands in the short term), this leads } \\
\text { to the accumulation of deadwood, meaning } \\
\text { that large fires eventually break out with } \\
\text { detrimental effects. In contrast, an ER } \\
\text { management perspective (adopting a wider } \\
\text { spatial and temporal scale view) would allow } \\
\text { frequent smaller fires in parts of the woodland } \\
\text { system [4]. }\end{array}$ & $\begin{array}{l}\text { perspective then management recommendations would not } \\
\text { be at odds (i.e. the stability of functions across the whole } \\
\text { woodland system in the longer term is maintained by not } \\
\text { continually suppressing fires locally). As highlighted in the } \\
\text { main text, clarification on the system type and spatial and } \\
\text { temporal scales of interest is critical to avoid researchers } \\
\text { talking at cross purposes. Note also, that under a more } \\
\text { recent suggestions the focus of management might not be } \\
\text { for stability of ecosystem function per se, but just provision } \\
\text { consistently above some socially acceptable threshold, } \\
\text { although the two are likely to be correlated) [3]. }\end{array}$ \\
\hline $\begin{array}{l}\text { ER literature focusses on the } \\
\text { system state whilst BE-F } \\
\text { studies are concerned with } \\
\text { the ecosystem functions }\end{array}$ & $\begin{array}{l}\text { This statement does not hold true and in fact } \\
\text { research fields are guilty of ambiguity in what } \\
\text { variables are being measured (i.e. 'resilience of } \\
\text { what to what'?). In the ER literature the focus } \\
\text { of resilience is varyingly defined as the system } \\
\text { state (i.e. state variables), the relationships } \\
\text { between variables in a system, or the ways of } \\
\text { functioning (i.e. ecosystem functions [4]. In BE- } \\
\text { F literature the focus has traditionally been on } \\
\text { measuring stability in ecosystem functions, but } \\
\text { some more recent studies (which might } \\
\text { arguably be included in the 'BE-F literature'), } \\
\text { have focused on measuring system states (e.g. } \\
\text { species composition)[e.g. 2]. }\end{array}$ & $\begin{array}{l}\text { First, clarity is essential in order to reduce confusion [11] and } \\
\text { authors should be careful to avoid ambiguity. Second, a } \\
\text { conceptual framework needs internal coherency. It is } \\
\text { contradictory to think about system variables (such as } \\
\text { species composition) remaining constant as the definition of } \\
\text { a resilient system [2], whilst also defining resilience as the } \\
\text { capacity to re-organise (e.g. through species turnover) to } \\
\text { retain function [4]. Both research fields recognize the truth in } \\
\text { this. ER literature holds that systems are dynamic and may } \\
\text { operate away from equilibrium (i.e. they move around within } \\
\text { a 'domain of stability', also sometimes called the 'normal } \\
\text { operating range'), with resilience as the tendency to remain } \\
\text { in this domain. Thus, internal re-organisations of system } \\
\text { states may be essential in allowing a system to absorb } \\
\text { disturbances whilst remaining in a stability domain which } \\
\text { delivers better ecosystem function. Similarly, BE-F literature } \\
\text { documents in detail both empirically and theoretically [6] }\end{array}$ \\
\hline
\end{tabular}




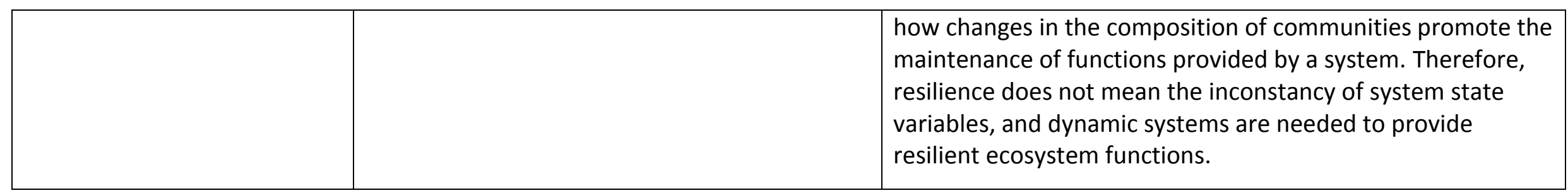




\section{Acknowledgements}

This article's author group is part of the Tansley Working Groups initiative sponsored by the UK Natural Environment Research Council (NERC: http://www.nerc.ac.uk/). THO was supported by the Wessex BESS project (ref. NE/J014680/1) within the NERC Biodiversity Ecosystem Services Sustainability (BESS) programme. VP was supported by Fundação para a Ciência e a Tecnologia (BPD/80726/2011). Contributions of OLP were supported by the University of Zurich Research Priority Program on 'Global Change and Biodiversity' and SNSF Project 31003A_137921 'Predicting community responses to environmental change'. 


\section{References}

1. Mori, A.S. (2015) ** Typesetter to add **. Trends Ecol. Evol.

2. Nimmo, D.G., Mac Nally, R., Cunningham, S.C., Haslem, A., and Bennett, A.F. (2015) Vive la résistance: reviving resistance for 21st century conservation. Trends Ecol. Evol. 30, 516-523.

3. Oliver, T.H., Heard, M.S., Isaac, N.J.B., Roy, D.B., Procter, D.A., Eigenbrod, F., Freckleton, R.P., Hector, A., Orme, C.D.L., Petchey, O.L., Proenca, V., Raffaelli, D., Suttle, K.B., Mace, G.M., Martin-Lopez, B., Woodcock, B.A., and Bullock, J.M. (2015) Biodiversity and the resilience of ecosystem services. Trends Ecol. Evol. 30, 673-684.

4. Gunderson, L., Allen, C.R., and Holling, C.S. (2010) Foundations of Ecological Resilience Island Press.

5. Newton, A. and Cantarello, E. (2015) Restoration of forest resilience: An achievable goal? New Forests 46, 645-668.

6. Loreau, M. and de Mazancourt, C. (2013) Biodiversity and ecosystem stability: a synthesis of underlying mechanisms. Ecol. Lett. 16, 106-115.

7. Pasari, J.R., Levi, T., Zavaleta, E.S., and Tilman, D. (2013) Several scales of biodiversity affect ecosystem multifunctionality. PNAS 110, 10219-10222.

8. Reiss, J., Bridle, J.R., Montoya, J.M., and Woodward, G. (2009) Emerging horizons in biodiversity and ecosystem functioning research. Trends Ecol. Evol. 24, 505-514.

9. Karp, D.S., Ziv, G., Zook, J., Ehrlich, P.R., and Daily, G.C. (2011) Resilience and stability in bird guilds across tropical countryside. PNAS 108, 21134-21139. 
10. Dai, L., Vorselen, D., Korolev, K.S., and Gore, J. (2012) Generic Indicators for Loss of Resilience Before a Tipping Point Leading to Population Collapse. Science 336, 11751177.

11. Grimm, V. and Wissel, C. (1997) Babel, or the ecological stability discussions: an inventory and analysis of terminology and a guide for avoiding confusion. Oecologia 109, 323-334.

12. Truchy, A., Angeler, D.G., Sponseller, R.A., Johnson, R.K., and McKie, B.G. (in press) Linking Biodiversity, Ecosystem Functioning and Services, and Ecological Resilience: Towards an Integrative Framework for Improved Management. Advances in Ecological Research http://dx.doi.org/10.1016/bs.aecr.2015.09.004. 



\section{Supplementary Material}

\section{A synthesis is emerging between biodiversity-ecosystem function and ecological resilience research - Reply to Mori}

Tom H. Oliver, ${ }^{1,2 *}$ Matthew S. Heard, ${ }^{2}$ Nick J.B.Isaac, ${ }^{2}$ David B. Roy, ${ }^{2}$ Deborah Procter, ${ }^{3}$ Felix Eigenbrod, ${ }^{4}$ Rob Freckleton, ${ }^{5}$ Andy Hector, ${ }^{6}$ C. David L. Orme, ${ }^{7}$ Owen L. Petchey, ${ }^{8}$ Vânia Proença, ${ }^{9}$ David Raffaelli, ${ }^{10}$ K. BlakeSuttle, ${ }^{11}$ Georgina M.Mace, ${ }^{12}$ Berta Martín-López, ${ }^{13,14}$ Ben A.Woodcock, ${ }^{2}$ and James M.Bullock ${ }^{2}$

${ }^{1}$ University of Reading, Whiteknights, PO Box 217, Reading, Berkshire, RG6 6AH, UK

${ }^{2}$ NERC Centre for Ecology and Hydrology, Wallingford, OX10 8BB, UK

${ }^{3}$ Joint Nature Conservation Committee, UK

${ }^{4}$ University of Southampton, UK

${ }^{5}$ University of Sheffield, UK

${ }^{6}$ Department of Plant Sciences, University of Oxford, UK

${ }^{7}$ Imperial College London, UK

8 Institute of Evolutionary Biology and Environmental Studies, University of Zurich, Switzerland

${ }^{9}$ Instituto Superior Técnico, University of Lisbon, Portugal

${ }^{10}$ University of York, UK

${ }^{11}$ Department of Earth and Planetary Science, University of California, Berkeley, CA, USA

${ }^{12}$ University College London, UK

${ }^{13}$ Faculty of Sustainability, Institute of Ethics and Transdisciplinary Sustainability Research, Leuphana University of Lüneburg, Germany Corresponding author: T.H. Oliver (t.oliver@reading.ac.uk) 
Table S1 - Perceived discrepancies in biodiversity-ecosystem function (B-EF) versus ecological resilience (ER) literature and potential reconciliation. This table is a more extensively referenced version of Table 1 in the main text.

\begin{tabular}{|c|c|c|}
\hline Perceived discrepancy & Further details & Clarification/ potential reconciliation \\
\hline $\begin{array}{l}\text { B-EF literature focusses on } \\
\text { stability and equilibrium and } \\
\text { ignores the existence of } \\
\text { alternate stable states. The } \\
\text { existence of alternate stable } \\
\text { states is a requisite for ER. }\end{array}$ & $\begin{array}{l}\text { ER definitions concern the likelihood of a } \\
\text { system crossing thresholds between alternate } \\
\text { stable states ('regime shifts' [8]). A system } \\
\text { need not have high constancy to be resilient- it } \\
\text { may be dynamic around a semi-stable } \\
\text { equilibrium (i.e. staying within a 'domain of } \\
\text { attraction'). Therefore ER authors have } \\
\text { suggested that stability is not a relevant } \\
\text { measure of resilience and may even lead to } \\
\text { contradictory management outcomes (also see } \\
\text { below). }\end{array}$ & $\begin{array}{l}\text { The key point here is whether the focus is on system state } \\
\text { variables or ecosystem functions provided by the system. If } \\
\text { the focus is the latter, then studies do not rely on quantifying } \\
\text { return to some equilibrium state; nor, indeed, do they need } \\
\text { to posit the existence of alternate stable states as do ER } \\
\text { studies (and some authors have questioned the extent to } \\
\text { which these really exist [9]). With a focus on ecosystem } \\
\text { functions, any system is suitable for study, even those that } \\
\text { are managed far from any stable equilibrium (i.e. most } \\
\text { managed ecosystems). }\end{array}$ \\
\hline $\begin{array}{l}\text { Managing for stability of } \\
\text { ecosystem functions (as } \\
\text { informed under a B-EF } \\
\text { framework) can be }\end{array}$ & $\begin{array}{l}\text { This issue is often highlighted in the ER } \\
\text { literature with a frequently cited example } \\
\text { being the management of woodlands to } \\
\text { prevent fires. If fires are regularly suppressed } \\
\text { (i.e. to provide stable ecosystem functions }\end{array}$ & $\begin{array}{l}\text { Rather than a fundamental disagreement, the discrepancy } \\
\text { here is simply a result of a focus on different spatial and } \\
\text { temporal scales. If both approaches adopt a large-scale } \\
\text { perspective then management recommendations would not } \\
\text { be at odds (i.e. the stability of functions across the whole }\end{array}$ \\
\hline
\end{tabular}




\begin{tabular}{|c|c|c|}
\hline $\begin{array}{l}\text { detrimental in the longer } \\
\text { term. }\end{array}$ & $\begin{array}{l}\text { from woodlands in the short term), this leads } \\
\text { to the accumulation of deadwood, meaning } \\
\text { that large fires eventually break out with } \\
\text { detrimental effects. In contrast, an ER } \\
\text { management perspective (adopting a wider } \\
\text { spatial and temporal scale view) would allow } \\
\text { frequent smaller fires in parts of the woodland } \\
\text { system [10]. }\end{array}$ & $\begin{array}{l}\text { woodland system in the longer term is maintained by not } \\
\text { continually suppressing fires locally). As highlighted in the } \\
\text { main text, clarification on the system type and spatial and } \\
\text { temporal scales of interest is critical to avoid researchers } \\
\text { talking at cross purposes. Note also, that under a more } \\
\text { recent suggestions the focus of management might not be } \\
\text { for stability of ecosystem function per se, but just provision } \\
\text { consistently above some socially acceptable threshold, } \\
\text { although the two are likely to be correlated) }[11,12] \text {. }\end{array}$ \\
\hline $\begin{array}{l}\text { ER literature focusses on the } \\
\text { system state whilst BE-F } \\
\text { studies are concerned with } \\
\text { the ecosystem functions }\end{array}$ & $\begin{array}{l}\text { This statement does not hold true and in fact } \\
\text { research fields are guilty of ambiguity in what } \\
\text { variables are being measured (i.e. 'resilience of } \\
\text { what to what'? cf. [6,13,14]. In the ER } \\
\text { literature the focus of resilience is varyingly } \\
\text { defined as the system state (i.e. state } \\
\text { variables), the relationships between variables } \\
\text { in a system, or the ways of functioning (i.e. } \\
\text { ecosystem functions [10]. In BE-F literature the } \\
\text { focus has traditionally been on measuring } \\
\text { stability in ecosystem functions, but some } \\
\text { more recent studies (which might arguably be } \\
\text { included in the 'BE-F literature'), have focused } \\
\text { on measuring system states (e.g. species } \\
\text { composition)[15, 16]. }\end{array}$ & $\begin{array}{l}\text { First, clarity is essential in order to reduce confusion [5] and } \\
\text { authors should be careful to avoid ambiguity. Second, a } \\
\text { conceptual framework needs internal coherency. It is } \\
\text { contradictory to think about system variables (such as } \\
\text { species composition) remaining constant as the definition of } \\
\text { a resilient system [15, 16], whilst also defining resilience as } \\
\text { the capacity to re-organise (e.g. through species turnover) to } \\
\text { retain function [10]. Both research fields recognize the truth } \\
\text { in this. ER literature holds that systems are dynamic and may } \\
\text { operate away from equilibrium (i.e. they move around within } \\
\text { a 'domain of stability', also sometimes called the 'normal } \\
\text { operating range'), with resilience as the tendency to remain } \\
\text { in this domain. Thus, internal re-organisations of system } \\
\text { states may be essential in allowing a system to absorb } \\
\text { disturbances whilst remaining in a stability domain which } \\
\text { delivers better ecosystem function. Similarly, BE-F literature } \\
\text { documents in detail both empirically [12, 17, 18] and } \\
\text { theoretically [19, 20] how changes in the composition of } \\
\text { communities promote the maintenance of functions }\end{array}$ \\
\hline
\end{tabular}




\begin{tabular}{|l|l|l|}
\hline & provided by a system. Therefore, resilience does not mean \\
the inconstancy of system state variables, and dynamic \\
systems are needed to provide resilient ecosystem functions.
\end{tabular}

\section{References}

1. Hector, A. and Bagchi, R. (2007) Biodiversity and ecosystem multifunctionality. Nature 448, 188-190.

2. Lefcheck, J.S., Byrnes, J.E.K., Isbell, F., Gamfeldt, L., Griffin, J.N., Eisenhauer, N., Hensel, M.J.S., Hector, A., Cardinale, B.J., and Duffy, J.E. (2015) Biodiversity enhances ecosystem multifunctionality across trophic levels and habitats. Nat Commun 6.

3. Pasari, J.R., Levi, T., Zavaleta, E.S., and Tilman, D. (2013) Several scales of biodiversity affect ecosystem multifunctionality. PNAS 110, 10219-10222.

4. Dooley, Á., Isbell, F., Kirwan, L., Connolly, J., Finn, J.A., and Brophy, C. (2015) Testing the effects of diversity on ecosystem multifunctionality using a multivariate model. Ecol. Lett. 18, 1242-1251.

5. Grimm, V. and Wissel, C. (1997) Babel, or the ecological stability discussions: an inventory and analysis of terminology and a guide for avoiding confusion. Oecologia 109, 323-334. 
6. Carpenter, S., Walker, B., Anderies, J.M., and Abel, N. (2001) From Metaphor to Measurement: Resilience of What to What? Ecosystems 4, 765-781.

7. Quinlan, A.E., Berbés-Blázquez, M., Haider, L.J., and Peterson, G.D. (2015) Measuring and assessing resilience: broadening understanding through multiple disciplinary perspectives. J. Appl. Ecol., online early.

8. Scheffer, M., Carpenter, S., Foley, J.A., Folke, C., and Walker, B. (2001) Catastrophic shifts in ecosystems. Nature 413, 591-596.

9. Newton, A. and Cantarello, E. (2015) Restoration of forest resilience: An achievable goal? New Forests 46, 645-668.

10. Gunderson, L., Allen, C.R., and Holling, C.S. (2010) Foundations of Ecological Resilience Island Press.

11. Oliver, T.H., Heard, M.S., Isaac, N.J.B., Roy, D.B., Procter, D.A., Eigenbrod, F., Freckleton, R.P., Hector, A., Orme, C.D.L., Petchey, O.L., Proenca, V., Raffaelli, D., Suttle, K.B., Mace, G.M., Martin-Lopez, B., Woodcock, B.A., and Bullock, J.M. (2015) Biodiversity and the resilience of ecosystem services. Trends Ecol. Evol. 30, 673-684.

12. Allan, E., Weisser, W., Weigelt, A., Roscher, C., Fischer, M., and Hillebrand, H. (2011) More diverse plant communities have higher functioning over time due to turnover in complementary dominant species. PNAS 108, 17034-17039.

13. Brand, F.S. and Jax, K. (2007) Focusing the meaning(s) of resilience: resilience as a descriptive concept and a boundary object. Ecology and Society 12, 23. 
14. Mumby, P.J., Chollett, I., Bozec, Y.-M., and Wolff, N.H. (2014) Ecological resilience, robustness and vulnerability: how do these concepts benefit ecosystem management? Curr. Opin. Env. Sust. 7, 22-27.

15. Standish, R.J., Hobbs, R.J., Mayfield, M.M., Bestelmeyer, B.T., Suding, K.N., Battaglia, L.L., Eviner, V., Hawkes, C.V., Temperton, V.M., Cramer, V.A., Harris, J.A., Funk, J.L., and Thomas, P.A. (2014) Resilience in ecology: Abstraction, distraction, or where the action is? Biol. Cons. $177,43-51$

16. Nimmo, D.G., Mac Nally, R., Cunningham, S.C., Haslem, A., and Bennett, A.F. (2015) Vive la résistance: reviving resistance for 21st century conservation. Trends Ecol. Evol. 30, 516-523.

17. Tilman, D. (1996) Biodiversity: Population Versus Ecosystem Stability. Ecology 77, 350-363.

18. Cardinale, B.J., Wright, J.P., Cadotte, M.W., Carroll, I.T., Hector, A., Srivastava, D.S., Loreau, M., and Weis, J.J. (2007) Impacts of plant diversity on biomass production increase through time because of species complementarity. PNAS 104, 18123-18128.

19. Loreau, M. and de Mazancourt, C. (2013) Biodiversity and ecosystem stability: a synthesis of underlying mechanisms. Ecol. Lett. 16, 106115.

20. Morin, X., Fahse, L., de Mazancourt, C., Scherer-Lorenzen, M., and Bugmann, H. (2014) Temporal stability in forest productivity increases with tree diversity due to asynchrony in species dynamics. Ecol. Lett. 17, 1526-1535. 